\title{
Dietary unsaturated fatty acids influence preovulatory follicle characteristics in dairy cows
}

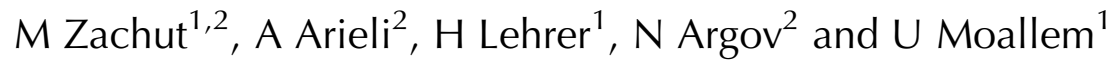 \\ ${ }^{1}$ Department of Dairy Cattle, Institute of Animal Sciences, Volcani Center, PO Box 6, Bet-Dagan 50250, Israel and \\ ${ }^{2}$ Department of Animal Science, Faculty of Agriculture, Hebrew University, Rehovot 76-100, Israel
}

Correspondence should be addressed to U Moallem; Email: uzim@volcani.agri.gov.il

\begin{abstract}
Dietary unsaturated fatty acids (UFAs) have been implicated in several reproductive processes in dairy cows through a variety of mechanisms. This study examined the effects of periparturient supplementation of rumen bypass fats low or high in proportion of UFAs (oleic and linoleic) on preovulatory follicle characteristics. Forty-two 256-day pregnant dairy cows were divided into three groups and were fed a control diet $(n=14)$ or supplemented with fats either low (LUFA; $n=14)$ or high (HUFA; $n=14)$ in UFAs. At 14-15 days following behavior estrus, the cows received a prostaglandin $F_{2 \alpha}$ injection and $48 \mathrm{~h}$ later $>7 \mathrm{~mm}$ follicles were aspirated. Progesterone $\left(P_{4}\right)$, androstenedione $\left(A_{4}\right)$, and estradiol $\left(E_{2}\right)$ were determined in the follicular fluid. Out of 75 follicles, 37 follicles that were aspirated between 55 and 70 days post partum were regarded as $E_{2}$-active follicles $\left(E_{2} / P_{4}\right.$ ratio $\left.>1\right)$ and subjected for further analysis. The diameter of preovulatory follicles was greater in cows fed HUFA than in those fed control or LUFA. The concentrations and content of $A_{4}$ and $E_{2}$ in follicles and $E_{2} / P_{4}$ ratio were higher in the HUFA group than in the other two groups. The P450 aromatase mRNA expression in granulosa cells that were collected from the aspirated preovulatory follicles was also higher in the HUFA cows than in the other groups. A significant correlation was observed between $E_{2}$ concentrations in preovulatory follicles and $E_{2}$ concentrations in plasma at aspiration. In conclusion, dietary UFA increased the size of and elevated steroid hormones in preovulatory follicles, which may be beneficial to consequent ovarian function.

Reproduction (2008) 135 683-692
\end{abstract}

\section{Introduction}

Dietary fat has been shown as beneficial to the reproductive system in dairy cows (Staples et al. 1998). Recently, it has been accepted that the composition of fatty acids (FAs) in the supplemented fat has a crucial role in determining the effect on reproduction (Mattos et al. 2000, Lucy 2001). There is some evidence that dietary unsaturated FAs (UFAs) positively affect ovarian function in dairy cows, although the precise mechanism is unknown (Staples et al. 1998, Robinson et al. 2002). Leroy et al. (2005) demonstrated that the saturated FAs palmitic (C16:0) and stearic (C18:0) had reduced the cleavage rate and the development rate of blastocysts in vitro.

UFAs are essential components of all cell membranes and the proportion of different UFAs in tissues of the reproductive tract reflect dietary consumption (Wathes et al. 2007). UFAs can influence reproductive processes through a variety of mechanisms; they provide the precursors for prostaglandins (PGs) synthesis and can modulate the expression patterns of many key enzymes involved in both PG and steroid metabolism (Wathes et al. 2007). It has been shown by Elmes et al. (2004) in pregnant ewes that increased consumption of linoleic acid (C18:2) elevated the proportion of arachidonic acid (C20:4) in maternal plasma and fetal tissues and enhanced the placental PGs production. Supplementation of rumen bypass polyunsaturated FA to ewes increased the number of follicles and oocytes in the ovaries and enhanced the number of high-quality oocytes (Zeron etal. 2002). Dietary linolenic acid (C18:3) has been shown to increase follicle diameter and elevate plasma estradiol $\left(\mathrm{E}_{2}\right)$ concentrations during the follicular phase (Robinson et al. 2002). These results suggest that dietary UFA may have a pivotal role in modulating follicular development, PGs secretion, and steroidogenesis.

Our hypothesis was that specific dietary FAs might have a role in regulation of steroidogenesis in preovulatory follicles. The objective of the present study was to compare the effects of periparturient supplementation of two rumen bypass dietary fats containing either a high or low proportion of UFAs (oleic and linoleic) on the characteristics of preovulatory follicles in dairy cows.

\section{Results}

\section{Milk production and dry matter intake}

The average milk production during the first 70 days post partum was $5 \%$ higher in the high proportion of UFAs (HUFA) and low proportion of UFAs (LUFA) groups as 
compared with control; 41.2, 43.3, and $43.1 \mathrm{~kg} /$ day for control, LUFA, and HUFA respectively (pooled S.E.M. $=0.6 ; P<0.02$ ), with no significant differences in $3.5 \%$ fat-corrected milk production. Daily average dry matter intake until 70 days post partum was similar between groups; 23.6, 23.2, and $23.6 \mathrm{~kg}$ for control, LUFA, and HUFA groups respectively (pooled S.E.M. $=0.2$ ). No differences between groups were observed in the calculated net energy balance of the cows until 70 days in lactation. The interval between calving and time of positive energy balance was longer in the HUFA group than in the control group $(P<0.04)$ but not from the LUFA group $(26.9,41.6$, and 44.2 days for control, LUFA, and HUFA groups respectively; pooled S.E.M. $=5.7$ ).

\section{Preovulatory follicles characteristics and hormones}

The average plasma progesterone $\left(\mathrm{P}_{4}\right)$ concentration was $5.12 \mathrm{ng} / \mathrm{ml}$ at the day of $\mathrm{PGF}_{2 \alpha}$ injection and $0.11 \mathrm{ng} / \mathrm{ml}$ at the day of aspiration with no differences between groups. Three cows that had a different pattern of plasma $\mathrm{P}_{4}$ concentrations from the expected (according to the experimental schedule) were excluded from the analysis. Aspirations that were conducted between 55 and 70 days post partum were subjected to further analysis.

Follicles were regarded as $E_{2}$ active whenever the $E_{2} / P_{4}$ ratio in $F F$ was $>1$ and regarded as $E_{2}$ inactive whenever the $E_{2} / P_{4}$ ratio was $\leq 1$ (Ireland \& Roche 1982). Thirty-seven out of seventy-five follicles larger than $7 \mathrm{~mm}(\sim 50 \%)$ that were aspirated were defined as $E_{2}$ active and these follicles were used for further analysis. The average number of $\mathrm{E}_{2}$-active follicles that were aspirated was 1.3 per cow in the control and LUFA groups, and 1.0 in the HUFA group with no significant differences between groups. The average diameter of the follicles aspirated from the HUFA group was larger than in the control and LUFA groups $(P<0.03$; Table 1). The volume of the follicles in the HUFA group tended to be larger than in the control and LUFA groups $(P<0.06$; Table 1$)$.

The concentrations of $\mathrm{P}_{4}$, androstenedione $\left(\mathrm{A}_{4}\right)$, and $\mathrm{E}_{2}$ in $F F$ of $E_{2}$-active follicles are presented in Fig. 1. The $P_{4}$ concentrations and content in FF did not differ between groups (Table 1 ; Fig. 1). The $\mathrm{A}_{4}$ concentrations in the HUFA group were $69 \%$ higher than in the control group $(P<0.04)$, and 4.8 -fold higher than in the LUFA group $(P<0.001)$. The $\mathrm{A}_{4}$ content (Table 1$)$ was 3 -fold higher in the HUFA group than in the control $(P<0.001)$, and 11.5fold higher than in the LUFA group $(P<0.001)$. The $\mathrm{A}_{4}$ concentrations were lower in LUFA as compared with the control $(P<0.04)$, but the $\mathrm{A}_{4}$ content of the FF did not differ between these two groups.

The FF concentrations of $E_{2}$ were $40 \%$ higher in the HUFA group than in the control group $(P<0.01)$, and threefold higher than in the LUFA group $(P<0.001$;
Table 1 Characteristics of preovulatory follicles from cows supplemented with fat high or low in unsaturated fatty acids (UFAs) proportion.

\begin{tabular}{lcccr}
\hline & \multicolumn{3}{c}{ Treatments $^{\mathrm{c}}$} & \\
\cline { 2 - 4 } & Control & LUFA & HUFA & S.E.M. \\
\hline n, cows & & & & \\
n, follicles & 12 & 9 & 9 & \\
Follicles per cow & 16 & 12 & 9 & \\
Diameter (mm) & 1.3 & 1.3 & 1.0 & 0.2 \\
Volume (ml) & $11.8^{\mathrm{b}}$ & $10.5^{\mathrm{b}}$ & $15.4^{\mathrm{a}}$ & 1.0 \\
Progesterone (ng) & 1.1 & 1.0 & 2.2 & 0.4 \\
Androstenedione (ng) & 136.9 & 136.8 & 211.6 & 75.7 \\
Estradiol (ng) & $136.9^{\mathrm{b}}$ & $36.0^{\mathrm{b}}$ & $416.7^{\mathrm{a}}$ & 70.6 \\
NEFA ( $\mu \mathrm{Eq} / \mathrm{l})$ & $1490.5^{\mathrm{b}}$ & $867.6^{\mathrm{b}}$ & $3523.6^{\mathrm{a}}$ & 539.0 \\
NEFA $(\mu \mathrm{Eq})$ & 219.8 & 211.8 & 178.9 & 39.0 \\
Insulin (pg/ml) & 198.3 & 228.5 & 416.5 & 87.6 \\
Insulin (pg) & 101.7 & 86.3 & 115.9 & 22.9 \\
& 96.7 & 95.7 & 225.3 & 53.3 \\
\hline
\end{tabular}

$\overline{\mathrm{a}, \mathrm{b}}$ Within rows, means with different superscript letters are statistically different $(P<0.05)$. NEFA, non-esterified fatty acids.

${ }^{\mathrm{C}}$ Treatments were: cows fed from 256 days of pregnancy a dry cow ration and post partum fed a lactating cow diet (CTL) or supplemented with a fat either containing a low (LUFA) or high (HUFA) proportion of unsaturated fatty acids. ${ }^{\mathrm{d}}$ Cows with at least one $\mathrm{E}_{2}$-active follicle.

Fig. 1). The $E_{2}$ content in HUFA was 2.4-fold higher than in the control $(P<0.01)$ and 4.1 -fold higher than in the LUFA group $(P<0.003$; Table 1$)$. The $\mathrm{E}_{2}$ concentrations in the LUFA group were $53 \%$ lower than in the control $(P<0.001)$, with no differences in $E_{2}$ content among these groups. The $E_{2} / P_{4}$ ratio was $47 \%$ higher in the HUFA group than in the control $(P<0.03)$ and 2.5 -fold higher than in the LUFA group $(P<0.001)$. The $\mathrm{E}_{2} / \mathrm{P}_{4}$ ratio was $41 \%$ lower in LUFA than in control $(P<0.05)$.

Concentrations and content of non-esterified fatty acids (NEFA) and insulin in FF are shown in Table 1. NEFA and insulin concentrations in FF did not differ between groups, but NEFA and insulin contents in FF tended to be higher in HUFA as compared with control $(P<0.09)$.

\section{Plasma $E_{2}$ concentrations at the day of follicle aspiration}

The concentration of $E_{2}$ in plasma at the day of follicle aspiration was examined in a subgroup of 14 randomly selected cows (four to five cows from each treatment). The concentration of $E_{2}$ in plasma at the day of follicle aspiration was numerically but not significantly higher in HUFA cows than in the control and LUFA cows (3.5, 4.9, and $5.1 \mathrm{pg} / \mathrm{ml}$ for control, LUFA, and HUFA groups respectively; pooled S.E.M. $=0.1$ ).

A positive correlation between $E_{2}$ concentrations in plasma at the day of follicle aspiration and $E_{2}$ concentrations in FF was observed $(r=0.55, P<0.01)$. Furthermore, the correlation between $E_{2}$ concentrations in plasma and the $E_{2}$ content (ng) in $F F$ was also significant $(r=0.48, P<0.03)$. No significant correlation was found between the diameter of the follicle and $E_{2}$ in plasma $(r=0.32, P<0.19)$. 

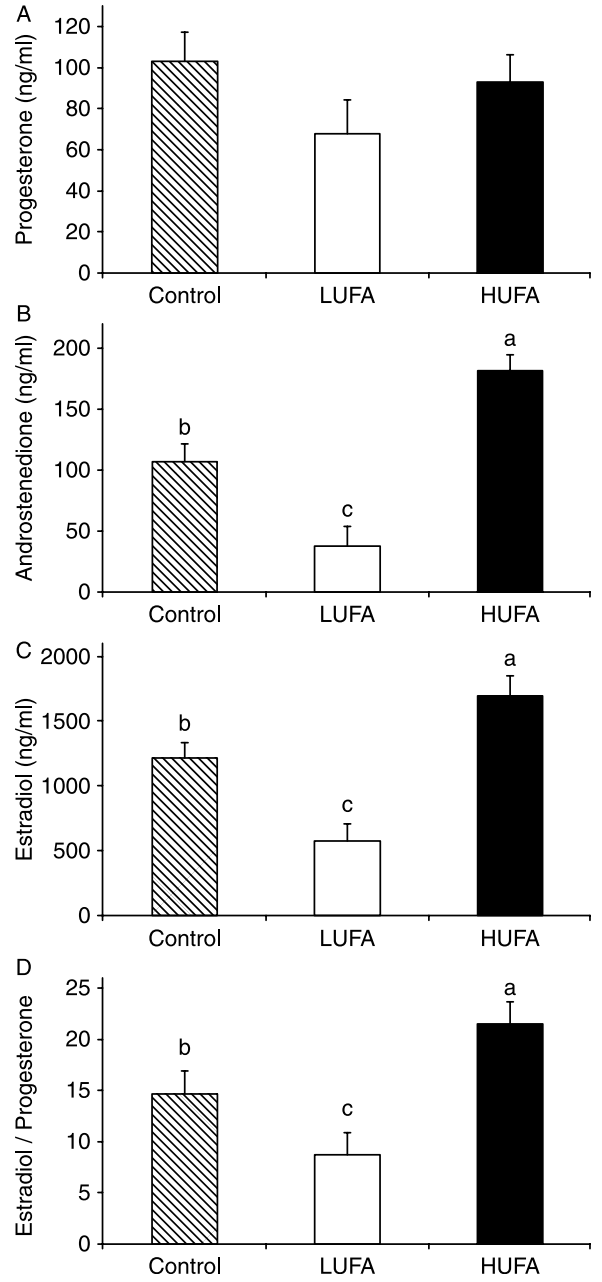

Figure 1 Concentrations of (A) progesterone, (B) androstenedione, (C) estradiol and (D) estradiol/progesterone ratio in FF of cows fed from 256 days of pregnancy a dry cow ration and post partum fed a lactating cow diet (CTL) or supplemented with a fat either containing a low (LUFA) or high (HUFA) proportion of unsaturated fatty acids. ${ }^{\mathrm{a}, \mathrm{b}, \mathrm{c}}$ Means with different superscript letters are statistically different $(P<0.05)$.

\section{P450 aromatase mRNA expression in granulosa cells}

The mRNA expression of P450 aromatase in granulosa cells was determined and the relative expression is presented in Fig. 2. The P450 aromatase mRNA expression in granulosa cells was similar between control and LUFA and was increased by one order of magnitude in HUFA cows in comparison with control $(P<0.016)$.

\section{FA profile in plasma and follicular fluid (FF)}

As shown in Table 2, the percentage of linoleic acid (C18:2) in plasma was higher in the HUFA group than in the LUFA group $(P<0.05)$ and similar to the control group. The total percentage of PUFA (C18:2 and longer FAs) was higher in HUFA than in LUFA (Table 2; $P<0.05)$, and similar to the control group $(P<0.12)$.

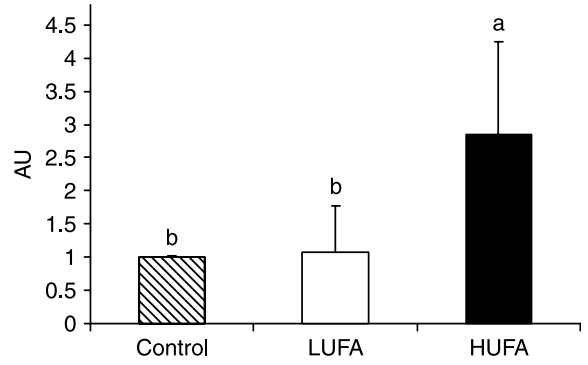

Figure $2 \mathrm{P} 450$ aromatase mRNA relative expression in granulosa cells obtained from preovulatory follicles of cows fed from 256 days of pregnancy a dry cow ration and post partum fed a lactating cow diet (CTL) or supplemented with a fat either containing a low (LUFA) or high (HUFA) proportion of unsaturated fatty acids. ${ }^{\mathrm{a}, \mathrm{b}}$ Means with different superscript letters are statistically different $(P<0.05)$.

The total percentage of saturated FAs tended to be higher in LUFA compared with HUFA (Table 2; $P<0.08$ ).

The FA profile in FF was analyzed in 30 out of 37 $E_{2}$-active follicles, since not all follicles had sufficient volume of FF for analysis. As shown in Table 3, the FA profile in FF did not differ between treatments, except for the percentage of arachidonic acid (C20:4), which was lower in the LUFA group than in the control group $(P<0.05)$, but was not different from that in the HUFA group.

\section{Relationship between FF hormones, insulin, and NEFA}

Across treatments, correlation coefficients between FF hormones, insulin, and NEFA are presented in Table 4. The content of $\mathrm{P}_{4}, \mathrm{~A}_{4}$, and $\mathrm{E}_{2}$ in $\mathrm{FF}$ was positively correlated with insulin and NEFA contents in FF. Furthermore, $E_{2}$ content in FF was positively correlated with $\mathrm{P}_{4}$ and $\mathrm{A}_{4}$ contents in FF. $E_{2}$ concentrations in FF was positively correlated with NEFA, $\mathrm{A}_{4}$ content, and $\mathrm{P}_{4}$ concentrations

Table 2 Fatty acid profile in plasma at the day of follicle aspiration.

\begin{tabular}{lcccc}
\hline & \multicolumn{3}{c}{ Treatments $^{\mathrm{c}}$} \\
\cline { 2 - 4 } & Control & LUFA & HUFA & s.E.M. \\
\hline$n$ & 12 & 9 & 9 & \\
C14:0 & 1.66 & 1.53 & 1.49 & 0.09 \\
C14:1 & 0.72 & 0.71 & 0.68 & 0.08 \\
C16:0 & 13.31 & 13.91 & 13.14 & 0.41 \\
C16:1 & 1.23 & 1.46 & 1.27 & 0.19 \\
C18:0 & 12.56 & 13.35 & 12.29 & 0.47 \\
C18:1 & 8.65 & 8.99 & 8.57 & 0.39 \\
C18:2 & $55.36^{\mathrm{a}, \mathrm{b}}$ & $53.68^{\mathrm{b}}$ & $56.24^{\mathrm{a}}$ & 0.87 \\
C18:3 & 1.80 & 1.73 & 1.71 & 0.10 \\
C20:3 & 2.35 & 2.54 & 2.55 & 0.16 \\
C20:4 & 2.18 & 2.10 & 2.05 & 0.22 \\
Saturated fatty acids & $27.53^{\mathrm{a}, \mathrm{b}}$ & $28.79^{\mathrm{a}}$ & $26.92^{\mathrm{b}}$ & 0.69 \\
Polyunsaturated fatty acids & $61.69^{\mathrm{a}, \mathrm{b}}$ & $60.05^{\mathrm{b}}$ & $62.55^{\mathrm{a}}$ & 0.88 \\
& & & &
\end{tabular}

$\overline{a, b}$ Within rows, means with different superscript letters are statistically different $(P<0.05)$.

${ }^{c}$ Treatments were: cows fed from 256 days of pregnancy a dry cow ration and post partum fed a lactating cow diet (CTL) or supplemented with a fat either containing a low (LUFA) or high (HUFA) proportion of unsaturated fatty acids. 
Table 3 Fatty acid profile in follicular fluid of estradiol $\left(E_{2}\right)$-active follicles.

\begin{tabular}{lcccc}
\hline & \multicolumn{3}{c}{ Treatments $^{\mathrm{c}}$} \\
\cline { 2 - 4 } & Control & LUFA & HUFA & \\
\hline$n$ & 11 & 10 & 9 & \\
S.E.M. & & \\
C14:0 & 2.40 & 2.80 & 2.86 & 0.28 \\
C16:0 & 1.12 & 2.50 & 1.10 & 0.15 \\
C16:1 & 15.52 & 14.03 & 16.24 & 0.86 \\
C18:0 & 1.74 & 1.65 & 1.70 & 0.15 \\
C18:1 & 11.43 & 11.46 & 11.46 & 0.42 \\
C18:2 & 9.43 & 9.78 & 9.15 & 0.39 \\
C18:3 & 51.74 & 52.47 & 51.99 & 0.95 \\
C20:3 & 1.67 & 1.57 & 1.66 & 0.09 \\
C20:4 & 1.88 & 1.96 & 1.97 & 0.10 \\
Saturated fatty acids & $2.25^{\mathrm{a}}$ & $1.79^{\mathrm{b}}$ & $1.87^{\mathrm{a}, \mathrm{b}}$ & 0.17 \\
Polyunsaturated fatty acids & 26.95 & 25.49 & 27.70 & 1.03 \\
& 57.55 & 57.78 & 57.48 & 0.97 \\
\hline
\end{tabular}

a,b Within rows, means with different superscript letters are statistically different $(P<0.05)$.

${ }^{\mathrm{C}}$ Treatments were: cows fed from 256 days of pregnancy a dry cow ration and post partum fed a lactating cow diet (CTL) or supplemented with a fat either containing a low (LUFA) or high (HUFA) proportion of unsaturated fatty acids.

in FF. The NEFA content in FF was positively correlated with insulin content and $\mathrm{P}_{4}$ concentrations in FF. Other correlations were not statistically significant.

\section{Relationship between follicular fluid FA concentrations and hormones}

Correlations were examined between follicular fluid $\mathrm{P}_{4}$, $A_{4}$, and $E_{2}$ concentrations and specific FA concentrations (Table 5). A positive correlation was found between $\mathrm{P}_{4}$ and $\mathrm{E}_{2}$ concentrations in $\mathrm{FF}$ and concentrations of $\mathrm{C} 16: 0, \mathrm{C} 18: 1, \mathrm{C} 18: 2, \mathrm{C} 18: 3$, and total FA in FF $(P<0.05) . \mathrm{A}_{4}$ concentrations in $\mathrm{FF}$ had a positive correlation with the concentrations of C16:0, C18:2, and total FA in FF $(P<0.05)$. The concentration of C20:4 in FF was positively correlated with the concentrations of $\mathrm{P}_{4}(P<0.03)$.

\section{NEFA and insulin in $E_{2}$-active or $E_{2}$-inactive follicles}

A total of 75 follicles were aspirated; 37 follicles were regarded as $E_{2}$ active and 38 follicles were regarded as $E_{2}$ inactive. Across treatments, analysis showed that insulin concentration was 4.2 -fold $(P<0.06)$ and insulin content was 2.9-fold $(P<0.0001)$ higher in $\mathrm{FF}$ from $\mathrm{E}_{2}$-active follicles as compared with $\mathrm{E}_{2}$-inactive follicles (Table 6). Furthermore, NEFA concentrations and content were 3.3- and 4.9-fold higher in $\mathrm{E}_{2}$-inactive follicles than in $\mathrm{E}_{2}$-active follicles respectively (Table 6; $P<0.0001$ ).

\section{Discussion}

To our knowledge, this is the first study in which dietary UFA had an effect on preovulatory follicle characteristics in dairy cows. In the present study, the concentrations and content of $A_{4}$ and $E_{2}$ in preovulatory follicles of cows supplemented with fat that contained high proportion of UFA were enhanced compared with control or cows that were supplemented with fat that contained low proportion of UFA. The mRNA expression of P450 aromatase was also increased in granulosa cells obtained from HUFA cows than in the control or LUFA cows.

In the current study, no significant correlation was observed between preovulatory follicles size and $E_{2}$ concentrations in plasma $(r=0.32 ; P<0.19)$, which is in agreement with a report by Wiltbank et al. (2006). However, a significant correlation was detected between $E_{2}$ concentrations in plasma and $E_{2}$ concentrations or $E_{2}$ content in follicles. The concentration of $E_{2}$ in plasma has been positively correlated with estrus duration and behavior in cattle (Mondal et al. 2006, Wiltbank et al. 2006). Pregnancy rates were related to the diameter of the preovulatory follicles and $E_{2}$ concentration in plasma in dairy cows (Lopes et al. 2007). It was also demonstrated by Botero-Ruiz et al. (1984) that follicles aspirated from women who conceived after in vitro fertilization had significantly higher $\mathrm{E}_{2}$ concentrations than similar follicles from women who failed to conceive. Furthermore, a relationship between peak serum $E_{2}$ concentrations and pregnancy rate after embryo transfer on day 5 was also observed in human (Chen et al. 2003). In an in vitro study, Tesarik \& Mendoza (1995) demonstrated a direct effect of $E_{2}$ on fertilization and cleavage rate of mature oocytes. They also suggested a model in which $E_{2}$ impacts the cell surface by increasing the intracellular free $\left[\mathrm{Ca}^{2+}\right]$, which serves as a second messenger and contributes to capacitation and early post-fertilization development (Tesarik \& Mendoza 1995). Collectively, these findings indicate positive effects of $E_{2}$ concentrations in $F F$ on

Table 4 Across treatments $(n=37)$ correlation coefficients between follicular fluid hormones, NEFA and insulin in $E_{2}$-active follicles.

\begin{tabular}{lcccccc}
\hline Item & $\mathbf{P}_{\mathbf{4}}(\mathrm{ng})$ & $\mathbf{A}_{\mathbf{4}}(\mathrm{ng})$ & $\mathbf{E}_{\mathbf{2}}(\mathrm{ng})$ & $\mathrm{NEFA}(\mu \mathrm{Eq})$ & Insulin $(\mathrm{pg})$ & $\mathbf{E}_{\mathbf{2}}(\mathrm{ng} / \mathrm{ml})$ \\
\hline $\mathrm{P}_{4}(\mathrm{ng})$ & - & $\mathrm{NS}$ & $0.76^{+}$ & $0.88^{+}$ & $0.40^{*}$ & $\mathrm{NS}$ \\
$\mathrm{A}_{4}(\mathrm{ng})$ & $\mathrm{NS}$ & - & $0.77^{+}$ & $0.40^{*}$ & $0.34^{*}$ & $0.53^{+}$ \\
$\mathrm{E}_{2}(\mathrm{ng})$ & $0.76^{+}$ & $0.77^{+}$ & - & $0.79^{+}$ & $0.60^{+}$ & - \\
$\mathrm{NEFA}(\mu \mathrm{Eq})$ & $0.88^{+}$ & $0.40^{*}$ & $0.79^{+}$ & - & $0.53^{+}$ & $\mathrm{NS}$ \\
$\mathrm{NEFA}(\mu \mathrm{Eq} / \mathrm{l})$ & $\mathrm{NS}$ & $\mathrm{NS}$ & $\mathrm{NS}$ & - & $\mathrm{NS}$ & $0.31^{*}$ \\
$\mathrm{P}_{4}(\mathrm{ng} / \mathrm{ml})$ & - & $\mathrm{NS}$ & $0.45^{+}$ & $0.49^{+}$ & $\mathrm{NS}$ & $0.41^{*}$ \\
\hline
\end{tabular}

$\mathrm{P}_{4}$, progesterone; $\mathrm{A}_{4}$, androstenedione; $\mathrm{E}_{2}$, estradiol; NEFA, non-esterified fatty acid. ${ }^{*} P<0.05 ;{ }^{\dagger} P<0.0001$. 
Table 5 Across treatments $(n=30)$ correlation coefficients between follicular fluid fatty acids concentrations and hormones.

\begin{tabular}{|c|c|c|c|c|c|c|c|}
\hline Item & C16:0 & C18:1 & C18:2 & C18:3 & C20:3 & C20:4 & Total FA \\
\hline $\mathrm{P}_{4}(\mathrm{ng} / \mathrm{ml})$ & $0.49^{+}$ & $0.35^{*}$ & $0.45^{*}$ & $0.34^{*}$ & NS & $0.40^{*}$ & $0.46^{*}$ \\
\hline $\mathrm{A}_{4}(\mathrm{ng} / \mathrm{ml})$ & $0.47^{+}$ & NS & $0.32 *$ & NS & NS & NS & $0.35^{*}$ \\
\hline $\mathrm{E}_{2}(\mathrm{ng} / \mathrm{ml})$ & $0.58^{+}$ & $0.39^{*}$ & $0.43^{*}$ & $0.36^{*}$ & $0.49^{\dagger}$ & NS & $0.48^{\dagger}$ \\
\hline
\end{tabular}

$\mathrm{P}_{4}$, progesterone; $\mathrm{A}_{4}$, androstenedione; $\mathrm{E}_{2}$, estradiol; $\mathrm{FA}$, fatty acid. ${ }^{*} P<0.05,{ }^{\dagger} P<0.008$.

estrus characteristics in cattle and fertilization, cleavage rate and pregnancy rate in human. These findings make the enhancement of $E_{2}$ concentrations in FF of special interest, since it may increase the potential of successful pregnancy.

There is little information on the effects of dietary UFA on ovarian steroidogenesis. It has been found in two studies that feeding UFA increased $\mathrm{E}_{2}$ levels in plasma; Robinson et al. (2002) supplemented dairy cows with fats containing either high concentrations of $\mathrm{C} 18: 3$ or high concentrations of $\mathrm{C} 18: 2$ and observed higher $\mathrm{E}_{2}$ concentrations in plasma in the C18:3 treatment than in the control, with intermediate values in the C18:2 group. Lammoglia et al. (1997) also found increased $E_{2}$ concentrations in plasma throughout the first, but not the second estrous cycle after fat supplementation using rice bran (rich in C18:2). There is some evidence that dietary fat could increase $E_{2}$ content or concentrations in FF. Cows that were supplemented with fat that contained calcium salts of FA $(6.5 \% \mathrm{C} 18: 2)$ had higher $\mathrm{E}_{2}$ content in $\mathrm{E}_{2}$-active follicles as compared with the control group (Moallem et al. 1999). In our previous report that focused on the follicular development in early lactation, a tendency for higher concentrations of $E_{2}$ in $\mathrm{FF}$ from $\mathrm{E}_{2}$-active follicles that were aspirated on day 12 post partum was observed in cows that were supplemented with HUFA as compared with LUFA or control cows $(P<0.1$; Moallem et al. 2007). In the current study, cows that were supplemented with HUFA that contained $33.6 \%$ of $\mathrm{C} 18: 1$ and $30.5 \%$ of $\mathrm{C} 18: 2$ had higher concentrations and content of $\mathrm{E}_{2}$ in follicles than control or LUFA supplemented cows.

We also observed higher $E_{2} / P_{4}$ ratio in follicles from the HUFA group than in the control and LUFA groups (1.5- and 2.5 -fold higher respectively). It is well established that the $\mathrm{E}_{2} / \mathrm{P}_{4}$ ratio is one of the most precise indicators of follicles health (McNatty et al. 1979, Ireland \& Roche 1982). Andersen (1993) demonstrated a significant correlation between the pregnancy potential of human oocytes after in vitro fertilization and the $\mathrm{E}_{2}$ /androgen ratio in FF. The enhanced $E_{2}$ concentrations and content and the higher $\mathrm{E}_{2} / \mathrm{P}_{4}$ ratio in preovulatory follicles of the HUFA cows in the current study may contribute to an increased pregnancy potential as explained previously.

Although we did not observe differences in the percentage of C18:2 in FF between groups, across treatment data showed a positive correlation between the $\mathrm{C} 18: 2$ and $\mathrm{E}_{2}$ concentrations in FF $(r=0.43$; $P<0.02$ ). The mechanism behind the enhanced $E_{2}$ synthesis when feeding UFA is still unclear, however, several explanations have been suggested. Steroid synthesis requires increased expression of StAR protein, which mediates transfer of cholesterol from the cytosol to the inner mitochondrial membrane (Stocco \& Clark 1996). Linoleic acid can be converted to arachidonic acid that increases the expression of StAR (Wang et al. 2000). Wathes et al. (2007) suggested that arachidonic acid and its metabolites may indirectly affect the steroidogenic machinery via PGs. It was demonstrated by Wang et al. (2003) that inhibition of specific PGs endoperoxide synthase-2 (PTGS2) was associated with increased StAR expression and steroid output, which could be caused by a decrease in $\mathrm{PGF}_{2 \alpha}$ that inhibits StAR protein expression. However, in the current study, we did not observe differences in $\mathrm{P}_{4}$ concentrations and content between groups, which may not support this theory of elevated StAR activity. Elmes et al. (2004) and Cheng et al. (2005) reported that feeding ewes a diet with high C18:2 increased the in vitro and in vivo synthesis of $\mathrm{PGE}_{2}$ in placental membranes. This finding indicated that $\mathrm{C} 18: 2$ plays a role in regulation of $\mathrm{PG}$ synthesis and thus could affect steroidogenesis. It was reported by Sarel \& Widmaier (1995) that C18:2 stimulated the adrenal corticosterone synthesis, which demonstrated the effects of UFA on steroidogenesis in a variety of tissues. It was also suggested by Wathes et al. (2007) that UFA may alter the function of transcription factors and thus affect cellular enzymes that regulate PGs and steroids synthesis. Indeed, the expression of P450 aromatase mRNA was higher in granulosa cells of UFA cows compared with the control, which supports this theory. Although there is some evidence for the implication of UFA in steroidogenesis regulation, the mechanism behind this regulation is not clear and further research is required to elucidate this issue.

Preovulatory follicles from the HUFA group were larger and tended to have larger volume compared with

Table 6 Across treatments insulin and non-esterified fatty acids (NEFAs) in estradiol $\left(E_{2}\right)$-active and $E_{2}$-inactive follicles.

\begin{tabular}{lccc}
\hline & $\mathbf{E}_{\mathbf{2}}$ active & $\mathbf{E}_{\mathbf{2}}$ inactive & s.E.M. \\
\hline n, follicles & 37 & 38 & \\
Insulin $(\mathrm{pg} / \mathrm{ml})$ & $91.97^{\mathrm{a}}$ & $21.64^{\mathrm{b}}$ & 11.92 \\
Insulin content $(\mathrm{pg})$ & $117.55^{\mathrm{a}}$ & $41.12^{\mathrm{b}}$ & 28.43 \\
NEFA $(\mu \mathrm{Eq} / \mathrm{l})$ & $206.81^{\mathrm{b}}$ & $682.72^{\mathrm{a}}$ & 36.94 \\
NEFA content $(\mu \mathrm{Eq})$ & $260.12^{\mathrm{b}}$ & $1280.18^{\mathrm{a}}$ & 194.7 \\
\hline
\end{tabular}

a,b Within rows, means with different superscript letters are statistically different $(P<0.05)$. NEFA, non-esterified fatty acids. 
the control and LUFA follicles. There are some other reports in which increased diameter of preovulatory follicles were observed as a result of fat supplementation in dairy cows (Lucy et al. 1991, Moallem et al. 1999). It was shown by Bilby et al. (2006) that cows fed a diet enriched with C18:2 had larger follicles, which is in agreement with the current study.

Lower concentrations of $A_{4}$ and $E_{2}$ in preovulatory follicles of the LUFA cows than in the control was observed in the current study, with no differences in $A_{4}$ and $E_{2}$ contents. The $\mathrm{E}_{2} / \mathrm{P}_{4}$ ratio was also lower in LUFA than in control. Vanholder et al. (2005) showed that saturated FA had a toxic effect on bovine granulosa cell growth and function in vitro, and similar effects were observed in human granulosa cells (Mu et al. 2001). It was also reported by $\mathrm{Mu}$ et al. (2001) that supplementation of arachidonic acid antagonized the saturated FA-induced apoptosis in granulosa cells. Leroy et al. (2005) demonstrated that in vitro addition of saturated FA (C16:0 and C18:0) to oocytes during maturation had negative effects on maturation, fertilization, cleavage rate, and blastocysts yield. These findings indicate that saturated FA may have an adverse effect on granulosa cells, which might partly explain the lower concentrations of $\mathrm{A}_{4}$ and $\mathrm{E}_{2}$ in the preovulatory follicles of the LUFA cows. In the current study, we indeed found that the percentage of saturated FA in plasma was higher in the LUFA group than in the HUFA group, but not than that of the control. When examining the FA profile in FF, we also observed lower percentage of arachidonic acid (C20:4) in FF of LUFA than in control. As mentioned above, arachidonic acid has a positive effect on steroidogenesis and it might be that the LUFA follicles had insufficient arachidonic acid and consequently lower steroidogenic hormones compared with the control.

Cell culture studies demonstrated a dependence of bovine granulosa cells on the presence of physiological concentrations of insulin (Gutierrez et al. 1997). Armstrong et al. (2002) observed a correlation between circulating insulin concentrations and $\mathrm{E}_{2}$ production in cultured granulosa cells. In the current study, we observed a tendency for higher content of insulin in HUFA follicles that had higher concentrations of $E_{2}$ compared with the control follicles. Insulin content was also positively correlated with $\mathrm{P}_{4}, \mathrm{~A}_{4}$, and $\mathrm{E}_{2}$ contents in FF. Our results confirm these previous findings in which insulin plays a significant role in follicle function.

Data from the present study also showed that the $E_{2}$ inactive follicles had 3.3-fold higher concentration and 4.9-fold higher content of NEFA than $\mathrm{E}_{2}$-active follicles. The content of the FF is assumed to be derived from the vasculature in the surrounding thecal layers (Clarke et al. 2006). However, the NEFA concentration in plasma of cows at that stage of lactation (55-70 days post-calving) is generally lower than that observed in the $E_{2}$-inactive follicles in the current study (Leroy et al. 2005). Moreover, Leroy et al. (2005) did not observe a constant association between NEFA concentrations in plasma and FF. In advanced stages of atresia, the granulosa cells have degenerated, and the FF is filled with cellular debris (Van Wezel et al. 1999). Therefore, we suggest that the increase in NEFA observed in $\mathrm{E}_{2}$-inactive follicles may be due to the disintegration of granulosa cells, which causes a leakage of NEFA and other cellular content into the FF. However, when examining the $E_{2}$-active follicles in the current study, we observed a positive correlation between NEFA and $\mathrm{P}_{4}, \mathrm{~A}_{4}$, and $\mathrm{E}_{2}$ contents, which indicates that NEFA is not necessarily a negative indicator for steroidogenesis potential of the follicle.

In conclusion, dietary UFA increased the diameter and tended to increase the volume of preovulatory follicle that were aspirated between 55 and $70 \mathrm{~d}$ post partum. No differences were observed between groups in $\mathrm{P}_{4}$ concentrations and content in follicles, however, $\mathrm{A}_{4}$ and $E_{2}$ concentrations and content were higher in cows that were supplemented with HUFA than control or LUFA. Higher P450 aromatase mRNA expression was also demonstrated in granulosa cells that were collected from the aspirated follicles. The findings of the current study indicate beneficial effects of dietary UFA on the preovulatory follicles size and steroidogenesis, although the mechanism is not fully clear.

\section{Materials and Methods}

\section{Cows and treatments}

The experimental protocol of the study was approved by the Volcani Center Animal Care Committee and was conducted at the Volcani Center experimental farm in Bet Dagan, Israel. The study was conducted from September to April to avoid heat stress effects. Forty-two multiparous Israeli-Holstein dry dairy cows, 249-day pregnant (average live body weight $=648 \pm 8 \mathrm{~kg}$ ), were group-housed in covered loose pens with adjacent outside yards, which were equipped with a real-time electronic individual feeding system. The cows were stratified into three groups on the basis of previous lactation milk and fat, parity, body weight, and body condition score. All treatments commenced prepartum at 256 days of pregnancy as follows: (1) Control were fed a dry cow diet and post partum were fed a lactating cow diet according to National Research Council (NRC 2001) recommendations $(n=14)$; (2) LUFA were supplemented with $230 \mathrm{~g}$ /day per cow of a rumen-protected fat that contained a low proportion of UFAs (Energy Booster 100, Milk Specialties, Dundee, IL, USA), until 100 days post partum $(n=14)$ and (3) HUFA were supplemented with $215 \mathrm{~g}$ /day per cow of a rumen-protected fat that contained a high proportion of UFAs (Megalac-R, Church and Dwight, Princeton, NJ, USA) until 100 days post partum $(n=14)$. The composition and content of the pre- and postpartum diets are presented in Tables 7 and 8 respectively. The cows were fed ad libitum pre-and post partum. The FA profile of Energy Booster 100 was $28.2 \%$ palmitic acid (C16:0), 51.2\% stearic acid (C18:0), $8.4 \%$ oleic acid (C18:1), $1.5 \%$ linoleic acid (C18:2), $0.1 \%$ linolenic acid (C18:3), and $10.6 \%$ other FAs (measured as a percentage of total FA). The FA profile of Megalac-R was $17.4 \%$ 
Table 7 Ingredients and chemical composition of diets.

\begin{tabular}{|c|c|c|c|}
\hline \multirow[b]{2}{*}{ Ingredients } & \multicolumn{3}{|c|}{ Treatments $^{\mathrm{a}}$} \\
\hline & Control & LUFA & HUFA \\
\hline & \multicolumn{3}{|c|}{ Percentage of dry matter } \\
\hline Corn grain ground & 12.9 & 4.9 & 4.8 \\
\hline Barley grain & 6.9 & 5.9 & 5.8 \\
\hline Rapeseed meal & 0.4 & 0.3 & 0.3 \\
\hline Gluten meal & 1.2 & 1.0 & 1.0 \\
\hline Soybean meal & 1.9 & 1.6 & 1.6 \\
\hline Sunflower meal & 0.7 & 0.6 & 0.6 \\
\hline Gluten feed & 2.9 & 2.4 & 2.4 \\
\hline Cottonseed & 1.7 & 1.5 & 1.5 \\
\hline Wheat silage & 4.6 & 3.9 & 3.9 \\
\hline Corn silage & 4.5 & 3.8 & 3.7 \\
\hline Dried distillers grain & 1.4 & 1.2 & 1.2 \\
\hline Legume hay & 0.8 & 0.7 & 0.7 \\
\hline Oats hay & 59.0 & 69.6 & 70.0 \\
\hline Salt & 0.5 & 0.4 & 0.4 \\
\hline Calcium bicarbonate & 0.2 & 0.2 & 0.2 \\
\hline Vitamins and minerals & 0.04 & 0.03 & 0.03 \\
\hline \multicolumn{4}{|l|}{ Supplements } \\
\hline Energy Booster 100 & & 1.9 & \\
\hline Megalac-R & & & 1.7 \\
\hline \multicolumn{4}{|l|}{ Chemical composition } \\
\hline $\mathrm{NE}_{\mathrm{L}}, \mathrm{Mcal} / \mathrm{kg}$ & 1.48 & 1.49 & 1.49 \\
\hline Crude protein & 12.0 & 12.0 & 12.0 \\
\hline Ether extract & 1.5 & 3.0 & 2.9 \\
\hline Crude NDF & 45.0 & 48.0 & 49.0 \\
\hline $\mathrm{Ca}$ & 0.6 & 0.6 & 0.8 \\
\hline$P$ & 0.3 & 0.3 & 0.3 \\
\hline
\end{tabular}

$\mathrm{NE}_{\mathrm{L}}$, net energy for lactation; NDF, neutral detergent fiber.

${ }^{\mathrm{a}}$ Treatments were: cows fed from 256 days of pregnancy a dry cow ration and post partum fed a lactating cow diet (CTL) or supplemented with a fat either containing a low (LUFA) or high (HUFA) proportion of unsaturated fatty acids.

palmitic acid (C16:0), 2.1\% stearic acid (C18:0), 33.6\% oleic acid (C18:1), 30.5\% linoleic acid (C18:2), 2.4\% linolenic acid (C18:3), and 14\% other FAs. The diets were formulated to be isoenergetic. The energy contents of the supplements that were used in this study were calculated according to the manufacturer's specifications, which were 6.0 and $6.6 \mathrm{NE}_{\mathrm{L}} \mathrm{Mcal} / \mathrm{kg} \mathrm{DM}$ for Energy Booster 100 (LUFA) and Megalac-R (HUFA) respectively. Cows were milked thrice daily and milk production was recorded electronically (SAE, Kibbutz Afikim, Israel). The cows were weighed automatically thrice daily after each milking with a walking electronic scale. The individual daily energy balance was calculated as described previously (Moallem et al. 2007).

\section{Follicular fluid aspiration}

At 38-40 days post partum, ovaries of all cows were examined once for the presence of corpus luteum (CL) by ultrasonography (Scanner 200; Pie Medical, Maastricht, The Netherlands). Cows with ovaries that had a $\mathrm{CL}$ were injected with $2.5 \mathrm{ml} \mathrm{PGF}_{2 \alpha}$ analog (Estrumate; Coopers Animal Health Ltd, Berkhamsted, UK) to facilitate estrus. Cows without a CL were injected with $5 \mathrm{ml}$ gonadotropin-releasing hormone analog (0.02 mg buserelin; Receptal, Intervet International B.V. Boxmeer, Holland) to induce ovulation of large follicles, followed 7 days later by injection of $2.5 \mathrm{ml} \mathrm{PGF}_{2 \alpha}$. Cows that were observed for signs of
Table 8 Basal lactating cow diet ingredients and chemical composition.

\begin{tabular}{|c|c|c|c|}
\hline \multirow[b]{2}{*}{ Ingredients } & \multicolumn{3}{|c|}{ Treatments $^{\mathrm{a}}$} \\
\hline & Control & LUFA & HUFA \\
\hline \multicolumn{4}{|c|}{ Percentage of dry matter } \\
\hline Corn grain ground & 18.0 & 15.3 & 15.4 \\
\hline Barley grain rolled & 18.2 & 18.5 & 18.5 \\
\hline Rapeseed meal & 1.0 & 1.0 & 1.0 \\
\hline Corn gluten meal & 3.1 & 3.2 & 3.2 \\
\hline Soybean meal & 5.0 & 5.1 & 5.2 \\
\hline Sunflower meal & 1.7 & 1.8 & 1.8 \\
\hline Corn gluten feed & 7.5 & 7.6 & 7.6 \\
\hline Cottonseed & 4.6 & 4.7 & 4.7 \\
\hline Wheat silage & 12.1 & 12.4 & 12.4 \\
\hline Corn silage & 11.7 & 11.9 & 11.9 \\
\hline Dried distillers grain & 3.8 & 3.9 & 3.9 \\
\hline Molasses & 0.6 & 0.6 & 0.6 \\
\hline Vetch hay & 2.1 & 2.2 & 2.2 \\
\hline Oats hay & 8.6 & 8.8 & 8.8 \\
\hline Soybean oil & 0.1 & 0.1 & 0.1 \\
\hline Salt & 1.4 & 1.4 & 1.4 \\
\hline Calcium bicarbonate & 0.5 & 0.5 & 0.5 \\
\hline Vitamins and minerals & 0.1 & 0.1 & 0.1 \\
\hline Energy Booster 100 & & 1.0 & \\
\hline Megalac-R & & & 0.9 \\
\hline \multicolumn{4}{|l|}{ Chemical composition } \\
\hline $\mathrm{NE}_{\mathrm{L}}(\mathrm{Mcal} / \mathrm{kg})$ & 1.78 & 1.78 & 1.78 \\
\hline Crude protein & 17.2 & 17.0 & 17.0 \\
\hline RUP & 6.0 & 6.0 & 6.0 \\
\hline ADF & 19.4 & 19.4 & 19.4 \\
\hline NDF & 31.7 & 31.7 & 31.7 \\
\hline Ether extract & 3.55 & 4.45 & 4.55 \\
\hline $\mathrm{Ca}$ & 0.9 & 0.9 & 0.9 \\
\hline$P$ & 0.4 & 0.4 & 0.4 \\
\hline
\end{tabular}

$\mathrm{NE}_{\mathrm{L}}$, net energy for lactation; RUP, rumen undegradable protein; $A D F$, acid detergent fiber; NDF, neutral detergent fiber.

${ }^{a}$ Treatments were: cows fed from 256 days of pregnancy a dry cow ration and post partum fed a lactating cow diet (CTL) or supplemented with a fat either containing a low (LUFA) or high (HUFA) proportion of unsaturated fatty acids.

estrus visually or by pedometers (Computerized Dairy Management Systems, SAE AFIKIM, Afikim, Israel), received 14-15 days later a second injection of $2.5 \mathrm{ml} \mathrm{PGF}_{2 \alpha}$ to cause luteolysis and to enable preovulatory follicular development. Forty-eight hours after the second $\mathrm{PGF}_{2 \alpha}$ injection, aspiration of FF was conducted using the ovum pick up procedure (Moallem et al. 1999). The FF aspirations were performed as follows: cows were sedated with an i.m. injection of $1 \mathrm{ml}$ of $2 \%$ Rompun (XYL-M2 Veterinary, xylazine base $20 \mathrm{mg} / \mathrm{ml}$; VMD, Arendonk, Belgium) and were given a local anesthesia of $5 \mathrm{ml}$ of $2 \%$ lidocaine $\mathrm{HCl}(2 \%$ esracain, $200 \mathrm{mg} / 10 \mathrm{ml}$; Rafa Laboratories, Jerusalem, Israel) injected epidurally between the last sacral and first caudal vertebrae. Ovaries were examined and the diameters of the large follicles were measured; follicles $\geq 7 \mathrm{~mm}$ were aspirated. Each follicle was aspirated into a single tube, centrifuged, and the FF was stored at $-18{ }^{\circ} \mathrm{C}$ until analysis. After the separation of the FF, $1 \mathrm{ml}$ RNAlater (Sigma-Aldrich Inc.) was added to the residue of each tube and then they were frozen at $-18{ }^{\circ} \mathrm{C}$ until determination of mRNA of P450 aromatase in the granulosa cells.

Blood samples for determination of $\mathrm{P}_{4}$ were taken at the day of the second $\mathrm{PGF}_{2 \alpha}$ injection ( $48 \mathrm{~h}$ prior to follicular 
aspiration) and at the day of follicle aspiration from the jugular vein into vacuum tubes with lithium heparin (Becton Dickinson Systems, Cowley, England). Plasma was separated immediately from blood samples and stored at $-18^{\circ} \mathrm{C}$ until analysis.

\section{Chemical analysis}

Total mixed rations were sampled weekly and dry matter, crude protein, neutral detergent fiber (NDF), acid detergent fiber (ADF), calcium, and phosphate were determined. Feed samples were dried at $65{ }^{\circ} \mathrm{C}$ for $24 \mathrm{~h}$ and then ground to pass through $1.0 \mathrm{~mm}$ screen (Retsch S-M-100). The ground samples were dried at $100{ }^{\circ} \mathrm{C}$ for $24 \mathrm{~h}$ and analyzed for N (AOAC, 1990; method 984.13; Kjeltec Auto 1030 Analyzer, Tecator, Hoganas, Sweden), Ca (AOAC, 1990; method 935.13), P (AOAC, 1990; method 964.06), and NDF and ADF contents were determined with Ankom equipment (Ankom Technology, Fairport, NY, USA; NDF, using $\alpha$-amylase and sodium sulfite). Net energy for lactation $\left(\mathrm{NE}_{\mathrm{L}}\right)$ values was calculated using the NRC (2001) values except for the fat supplements. The rumen undegradable protein (RUP) values of most of the feedstuffs were from Arieli et al. (1989). The NRC (2001) RUP values were used for feedstuffs that were not examined in Arieli et al. (1989).

Concentrations of $\mathrm{P}_{4}$ and $\mathrm{E}_{2}$ in $\mathrm{FF}$, and plasma $\mathrm{P}_{4}$ were determined by RIA (Diagnostic Products, Los Angeles, CA, USA) as well as FF $A_{4}$ concentrations (Diagnostic Systems Laboratories, Webster, TX, USA). Concentrations of nonesterified FA (NEFA) in FF were determined by a NEFA kit (Wako NEFA C test kit; Wako Chemicals $\mathrm{GmbH}$, Neuss, Germany). Concentrations of insulin in FF were determined by RIA (Diagnostic Products).

To determine the concentrations of plasma $E_{2}, 1 \mathrm{ml}$ plasma samples were extracted with diethyl ether (HPLC, Bio Lab Ltd, Jerusalem, Israel) and then $\mathrm{E}_{2}$ was determined by RIA kit (Third Generation Estradiol kit, DSL-39100; Diagnostic Systems Laboratories).

FAs in plasma and FF were extracted (Moallem et al. 1999) and analysis of FA was performed with 5890 series 2 gas chromatograph (Hewlett-Packard) equipped with a capillary column (30 m×0.53 mm, $0.5 \mu \mathrm{m}$; Agilent Technologies, Santa Clara, CA, USA) and an FID detector. The column was maintained at $160{ }^{\circ} \mathrm{C}$ isothermal. Nitrogen was used as carrier gas with a linear velocity of $22 \mathrm{~cm} / \mathrm{s}$; injection volume was $2 \mu \mathrm{l}$. The injection port was maintained at $230{ }^{\circ} \mathrm{C}$ and the detector at $235^{\circ} \mathrm{C}$. Detector air flow was $400 \mathrm{ml} / \mathrm{min}$ and the hydrogen flow was $33 \mathrm{ml} / \mathrm{min}$. A known amount of C17:0 was added to the samples prior to extraction in order to determine the FA concentrations in the FF.

\section{P450 aromatase mRNA expression in granulosa cells}

\section{Total RNA isolation}

Total RNA was isolated from granulosa cells obtained from the aspirated preovulatory follicles using TRI reagent $(10 \mathrm{ml} / \mathrm{g}$ tissue) according to the manufacturer's protocol (MRC
Molecular Research Center, Cincinnati, OH, USA). RNA quality and quantity were assessed by spectrophotometric measurements at 260 and $280 \mathrm{~nm}$. Only high-purity (260-280 ratio between 1.75 and 2) RNA was used.

\section{$m R N A$ analysis}

First-strand cDNAs were synthesized from $5 \mu \mathrm{g}$ total RNA from each follicle using oligo $(\mathrm{dT})_{18}$ as the primer in the presence of MLV reverse transcriptase (Fermentas Inc., Hanover, MD, USA) for $1 \mathrm{~h}$ at $42{ }^{\circ} \mathrm{C}$. The cDNA was purified from the PCR mix using High Pure PCR Product Purification kit (Roche Diagnostics $\mathrm{GmbH}$ ).

\section{Real-time PCR}

Expression of P450 aromatase mRNA in preovulatory follicles was determined by real-time PCR carried out following the manufacturer's specifications using a GeneAmp 5700 sequence detection system (Applied Biosystems, Foster City, CA, USA). mRNA samples were reverse transcribed as described in the mRNA analysis section and $5 \mu \mathrm{l}$ cDNA was used in $50 \mu \mathrm{l}$ final volume for the PCR. CDNA was amplified by qPCR Mastermix for SYBR Green I, using primers designed by the Primer Express version 2.0.0 software (Applied Biosystems) as follows: forward 3'-GCCAAGAGCAACAAGCATATCAG-5' and reverse 3'-CTTGGAAAATTCACTCATCTGTTTGA-5'.

Relative mRNA expression of P450 aromatase was determined by the $\Delta \Delta C_{\mathrm{T}}$ quantification method as described previously by Livak \& Schmittgen (2001), using the relative expression of GAPDH mRNA as a reference. $C_{\mathrm{T}}$ stands for the threshold cycle, that is, the PCR cycle in which an increase in reporter fluorescence above a baseline signal can first be detected.

\section{Statistical analysis}

The continuous variables (milk and dry matter intake) were analyzed as repeated measurements using Proc Mixed of SAS software (version 8.1, SAS User's Guide 2000). The final model used was

$$
\begin{aligned}
Y_{i j k l m}= & \mu+T_{i}+L_{j}+C(T \times L)_{i j k}+\mathrm{DIM}_{i j k l}+\mathrm{DIM}_{i j k l} \\
& \times \mathrm{DIM}_{i j k l}+\mathrm{DIM}_{i j k l} \times \mathrm{DIM}_{i j k l} \times \mathrm{DIM}_{i j k l}+E_{i j k l m}
\end{aligned}
$$

where $\mu=$ overall mean, $T_{i}=$ treatment effect, ${ }_{i}=1-3, L_{j}=$ parity, $j=2$ or $>2, C(T \times L)_{i j k}=\operatorname{cow}_{k}$ nested in treatment ${ }_{i}$ and cow nested in parity ${ }_{j}$, DIM $_{i j k l}=$ day in milk as continuous variable, and $e_{i j k l m}=$ random residual. Whenever the quadratic or cubic effects were not significant, they were excluded from the model and the model was rerun. Milk production was analyzed using the previous lactation data as co-variable. Dry matter intake was analyzed using the pre-treatment body weight as co-variable. The follicle diameter, volume, hormones, NEFA, and FA profile and concentrations were 
analyzed using the general linear models procedure of SAS (2000). Across treatments correlations analysis were performed using the Proc REG procedure of SAS software (2000). The analysis of mRNA expression was carried out using the JMP (version 5.0.1, SAS Institute, Cary, NC, USA). Gene expression levels were compared using one-way ANOVA.

Least squares means and adjusted S.E.M. are presented in the tables and $P<0.05$ was accepted as significant unless otherwise stated.

\section{Acknowledgements}

This research was supported by Research Grant No. US-3422-03 $\mathrm{R}$ from BARD, The United States - Israel Binational Agricultural Research and Development Fund. The authors gratefully acknowledge the kind donation of Megalac-R by Church \& Dwight (Princeton, NJ, USA) and Energy Booster 100 by Milk Specialties (Dundee, IL, USA). They also thank the experimental dairy farm's team at the Volcani Center, Bet Dagan, Israel for their assistance with animal care. The authors declare that there is no conflict of interest that would prejudice the impartiality of this scientific work.

\section{References}

Andersen CY 1993 Characteristics of human follicular fluid associated with successful conception after in vitro fertilization. Journal of Clinical Endocrinology and Metabolism 77 1227-1234.

Arieli A, Bruckental I \& Smoler E 1989 Prediction of duodenal nitrogen supply from degradation or organic and nitrogenous matter in situ. Journal of Dairy Science 72 2532-2539.

Armstrong DG, Gong JG, Gardner JO, Baxter G, Hogg CO \& Webb R 2002 Steroidogenesis in bovine granulosa cells: the effect of short-term changes in dietary intake. Reproduction 123 371-378.

Bilby TR, Block J, do Amaral BC, Sa Filho O, Silvestre FT, Hansen PJ, Staples CR \& Thatcher WW 2006 Effects of dietary unsaturated fatty acids on oocyte quality and follicular development in lactating dairy cows in summer. Journal of Dairy Science 89 3891-3903.

Botero-Ruiz W, Laufer N, DeCherney AH, Polan ML, Haseltine FP \& Behrman HR 1984 The relationship between follicular fluid steroid concentration and successful fertilization of human oocytes in vitro. Fertility and Sterility $\mathbf{4 1}$ 820-826.

Chen CH, Zhang X, Barnes R, Confino E, Milad M, Puscheck E \& Kazer RR 2003 Relationship between peak serum estradiol levels and treatment outcome in in vitro fertilization cycles after embryo transfer on day 3 or day 5. Fertility and Sterility $8075-79$.

Cheng Z, Elmes M, Kirkup SE, Chin EC, Abayasekara DRE \& Wathes DC 2005 The effect of a diet supplemented with n-6 polyunsaturated fatty acid linoleic acid on prostaglandin production in early and late pregnant ewes. Journal of Endocrinology 184 167-178.

Clarke HG, Hope SA, Byers S \& Rodgers R 2006 Formation of ovarian follicular fluid may be due to the osmotic potential of large glycosaminoglycans and proteoglycans. Reproduction 132 119-131.

Elmes M, Tew P, Cheng Z, Kirkup SE, Abayasekara DRE, Calder PC, Hanson MA, Wathes DC \& Burdge GC 2004 The effect of dietary supplementation with linoleic acid to late gestation ewes on the fatty acid composition of maternal and fetal plasma and tissues and the synthetic capacity of the placenta for 2-series prostaglandins. Biochimica et Biophysica Acta 1686 139-147.

Gutierrez CG, Campbell BK \& Webb R 1997 Development of a longterm bovine granulosa cell culture system: induction and maintenance of estradiol production, response to follicle stimulating hormone and morphological characteristics. Biology of Reproduction 56 608-616.

Ireland JJ \& Roche F 1982 Development of antral follicles in cattle after prostaglandin-induced luteolysis: changes in serum hormones, steroids in follicles fluids and gonadotropin receptors. Endocrinology 111 2077-2086.

Lammoglia MA, Willard ST, Hallford DM \& Randel RD 1997 Effects of dietary fat on follicular development and circulating concentrations of lipids, insulin, progesterone, estradiol-17 beta, 13,14-dihydro-15-ketoprostaglandin $\mathrm{F}(2$ alpha), and growth hormone in estrous cyclic Brahman cows. Journal of Animal Science 75 1591-1600.

Leroy JLMR, Vanholder T, Mateusen B, Christophe A, Opsomer G, de Kruif A, Genicot G \& Van Soom A 2005 Non-esterified fatty acids in follicular fluid of dairy cows and their effect on developmental capacity of bovine oocytes in vitro. Reproduction 130 485-495.

Livak KJ \& Schmittgen TD 2001 Analysis of relative gene expression data using real-time quantitative PCR and the $2^{-\Delta \Delta C_{T}}$ method. Methods 25 402-408.

Lopes AS, Butler ST, Gilbert RO \& Butler WR 2007 Relationship of preovulatory follicle size, estradiol concentrations and season to pregnancy outcome in dairy cows. Animal Reproduction Science 99 34-43.

Lucy MC 2001 Reproductive loss in high-producing dairy cattle: where will it end? Journal of Dairy Science 84 1277-1293.

Lucy MC, Staples CR, Michel FM \& Thatcher WW 1991 Energy balance and size and number of ovarian follicles detected by ultrasonography in early postpartum dairy cows. Journal of Dairy Science 74 473-482.

Mattos R, Staples CR \& Thatcher WW 2000 Effects of dietary fatty acids on reproduction in ruminants. Reviews of Reproduction 5 38-45.

McNatty KP, Smith DM, Markis A, Osathanondh R \& Ryan KJ 1979 The production of progesterone, androgens, and estrogens by granulosa cells, thecal tissue, and stromal tissue from human ovaries in vitro. Journal of Clinical Endocrinology and Metabolism 49 687-699.

Moallem U, Folman Y, Bor A, Arav A \& Sklan D 1999 Effect of calcium soaps of fatty acids and administration of somatotropin on milk production, preovulatory follicular development, and plasma and follicular fluid lipid composition in high yielding dairy cows. Journal of Dairy Science 82 2358-2368.

Moallem U, Katz M, Lehrer H, Livshitz L \& Yakoby S 2007 Role of peripartum dietary propylene glycol or protected fats on metabolism and early postpartum ovarian follicles. Journal of Dairy Science 90 1243-1254.

Mondal M, Rajkhowa C \& Prakash BS 2006 Relationship of plasma estradiol-17beta, total estrogen, and progesterone to estrus behavior in mithun (Bos frontalis) cows. Hormones and Behavior 49 626-633.

Mu YM, Yanase T, Nishi Y, Tanaka A, Saito M, Jin CH, Mukasa C, Okabe T, Nomura M, Goto K et al. 2001 Saturated FFA's, palmitic acid and stearic acid, induce apoptosis in human granulosa cells. Endocrinology 142 3590-3597.

Robinson RS, Pushpakumara PGA, Cheng Z, Peters AR, Abayasekara DRE \& Wathes DC 2002 Effects of dietary polyunsaturated fatty acids on ovarian and uterine function in lactating dairy cows. Reproduction $\mathbf{1 2 4}$ 119-131.

Sarel I \& Widmaier EP 1995 Stimulation of steroidogenesis in cultured rat adrenocortical cells by unsaturated fatty acids. American Journal of Physiology 268 1484-1490.

SAS User's Guide 2000 Statistics, Version 8.1 Edition. Cary, NC: SAS Inst. Inc.

Staples CR, Burke JM \& Thatcher WW 1998 Influence of supplemental fats on reproductive tissues and performance of lactating cows. Journal of Dairy Science 81 856-871.

Stocco DM \& Clark BJ 1996 Role of steroidogenic acute regulatory protein (StAR) in steroidogenesis. Biochemical Pharmacology 51 197-205.

Tesarik J \& Mendoza C 1995 Nongenomic effects of $17 \beta$-estradiol on maturing human oocytes: relationship to oocyte developmental potential. Journal of Clinical Endocrinology and Metabolism 80 1438-1443.

Vanholder T, Leroy JLMR, Vansoom A, Opsomer G, Maes D, Coryn M \& de Kruif A 2005 Effect of non-esterified fatty acids on bovine granulosa cell steroidogenesis and proliferation in vitro. Animal Reproduction Science 87 33-44.

Wang X, Walsh LP, Reinhart AD \& Stocco DM 2000 The role of arachidonic acid in steroidogenesis and steroidogenic acute regulatory (StAR) gene and protein expression. Journal of Biological Chemistry 275 20204-20209. 
Wang XJ, Dyson MT, Jo Y, Eubank DW \& Stocco DM 2003 Involvment of 5-lipoxygenase metabolites of arachidonic acid in cyclic AMPstimulated steroidogenesis and steroidogenic acute regulatory protein gene expression. Journal of Steroid Biochemistry and Molecular Biology 85 159-166.

Wathes DC, Abayasekara DRE \& Aitken RJ 2007 Polyunsaturated fatty acids in male and female reproduction. Biology of Reproduction 77 190-201.

Van Wezel IL, Dharmarajan AM, Lavranos TC \& Rodgers RJ 1999 Evidence for alternative pathways of granulosa cell death in healthy and slightly atretic bovine antral follicles. Endocrinology 140 2602-2612.
Wiltbank M, Lopez H, Sartori R, Sangsritavong S \& Gumen A 2006 Changes in reproductive physiology of lactating dairy cows due to elevated steroid metabolism. Theriogenology 65 17-29.

Zeron Y, Sklan D \& Arav A 2002 Effect of polyunsaturated fatty acid supplementation on biophysical parameters and chilling sensitivity of ewe oocytes. Molecular Reproduction and Development 61 271-278.

Received 13 December 2007

First decision 29 January 2008

Accepted 1 February 2008 